\title{
ESPESSAMENTO DE MISTURAS DE LAMA E REJEITO DE FLOTAÇÃO *
}

\section{Resumo}

Thokozani Lehae Hanes Malinga ${ }^{1}$ Henrique Dias Gatti Turrer ${ }^{1}$ Luis Clauzio de Renno Machado ${ }^{1}$ Carlos Magno Nascimento ${ }^{1}$ Leandro Almeida Santos ${ }^{1}$

Ricardo Ligorio Soares ${ }^{1}$ Elias de Castro Fonseca ${ }^{1}$

O complexo Minas-Rio da Anglo American iniciou suas operações em agosto de 2014. A usina de tratamento produziu, em 2016, cerca de 15,5 milhões de toneladas secas de concentrado. O minério, explorado no município de Conceição do Mato Dentro (MG), passa pelas etapas de cominuição, classificação, concentração e separação sólidolíquido antes de ser bombeado por $529 \mathrm{~km}$ até o município de São João da Barra (RJ), onde é filtrado, estocado e embarcado para exportação. A lama e o rejeito da flotação são enviados para um espessador de 90 metros de diâmetro. Testes de sedimentação em bancada mostraram o efeito positivo da sedimentação dessa mistura de lamas e rejeito. A lama, composta predominantemente por partículas finas de hematita e argilo minerais, se adere a ao quartzo do rejeito, que possui maior diâmetro. Apesar dessa mistura aumentar a velocidade de sedimentação, ela propicia a formação de uma espuma com elevada estabilidade, devido a presença de finos da deslamagem e espumante da flotação. Foram feitos testes de bancada objetivando-se avaliar o efeito da retirada do rejeito da alimentação do espessador. A partir dos resultados foram traçados cenários com diferentes participações desse material e suas implicações no processo de sedimentação foram estimados.

Palavras-chave: Espessamento, lama, rejeito.

\section{Abstract}

\section{THICKENING OF SLIMES AND FLOTATION TAILINGS' MIXTURES}

Anglo American's Minas Rio complex began operations in August 2014. The processing plant in 2016, produced approximately 15,5 million tonnes of dry concentrate. The ore, extracted from Conceição Do Mato Dentro (MG) municipality goes through comminution, classification, concentration and solid-liquid separation before being pumped for 529 kilometers to São João da Barra (RJ) municipality, where it is filtered, stocked and shipped for export. The slimes and flotation tailings from the process are sent to a thickener which is 90 meters in diameter. Bench sedimentation tests which were conducted showed a positive effect on the sedimentation of this mixture of slimes and tailings. Slimes, which are predominantly composed of fine hematite particles and mineral clay, adhere to the quartz tailing which has a larger diameter. Although this mixture increases the settling velocity, it promotes the formation of a froth with increased stability, due to the presence of fines from de-sliming and the flotation frother. Bench tests were performed with the objective of evaluating the effect of the removal of the flotation tailings from the feed to the thickener. From the results, different scenarios were drawn with different proportions of this material in order to estimate the implications on the sedimentation process.

Keywords: Thickening, slimes, tailings.

1 Gerência de desenvolvimento de processos, Anglo American - Rodovia MG 10, Km 180, Córrego Pereira, Conceição do Mato Dentro, MG, Brasil. 


\section{INTRODUCTION}

Processing of iron ore using flotation requires an immense amount of water and as a result, recycling of water is a fundamental part of the process. Water is mainly recovered using thickeners where dense solids settle to the bottom of a thickener and are recovered whilst water gets recovered at the top. The same was designed for the Minas Rio Project where two thickeners; a slimes and tailings thickener and a concentrate thickener are used to recover water. Initially the project was designed such that the slimes and tailings thickener would treat the flotation tailings as well as the overflow of the de-sliming cyclones. This mixture is known to have a better settling performance because slimes; which are predominantly composed of fine hematite particles and mineral clay, adhere to the quartz tailing which has a larger diameter. Figure 1 below shows the Minas-Rio process flow diagram.

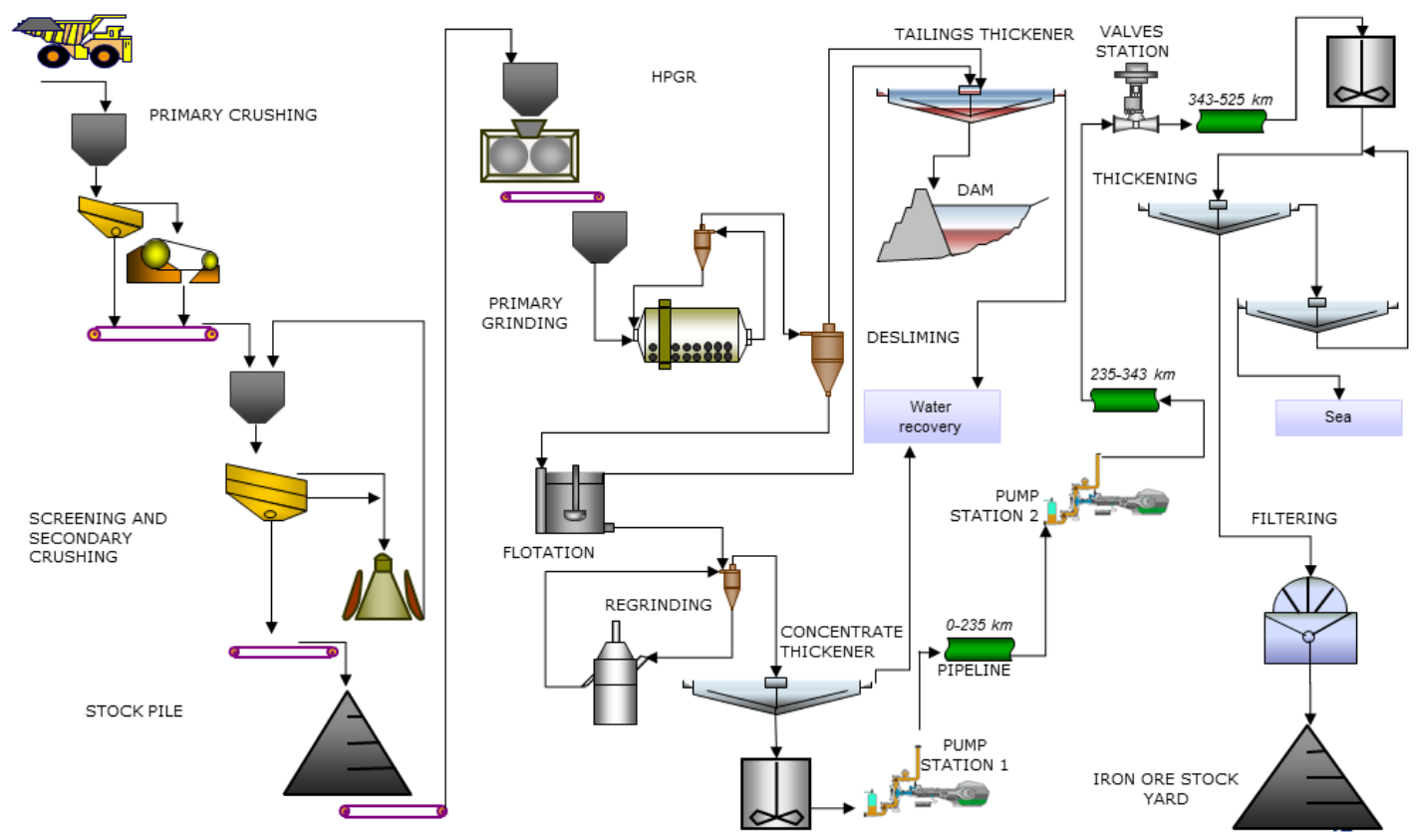

Figure 1. Minas-Rio process flow diagram.

Recently, a problem in the process has presented itself, whereby there is an increased amount of froth in the recycled water, leading to pump cavitation in the desliming area and therefore loss of material prior to flotation, resulting in mass recovery losses.

The origin of the frothing is not entirely understood, however it is suspected that it is as a result of the residual amine from the flotation tailings as well the ultrafine material from de-sliming.

In the project design it was initially defined that the mass ratio of tailings to slimes fed to the slimes thickener would be $90 \%$ to $10 \%$ respectively. However, because of the frothing, the Operations Team is currently exploring the effect of bypassing the tailings from flotation and directing them to the tailings dam as opposed to the thickener. This then implies that only the de-sliming overflow would be sent to the thickener. 


\subsection{Objectives}

The objective of this work was to evaluate sedimentation of slimes in order to understand how the parameters; slurry $\mathrm{pH}$, flocculant type and flocculant dosage affect settling and water recovery in a thickening process.

\section{$1.2 \quad$ Literature review}

Thickening is a widely used cost effective solid-liquid separation method which results in two streams; an underflow with minimal liquid and an overflow with minimal solids (Parker et al, 2016). Various factors can affect thickener performance some of which include slurry feed density which plays a role in efficient flocculation, as well as the type and dosage of flocculant (McIntosh, 2009).

Some tests have been conducted in thickening in order to evaluate how thickening of a mixture of flotation tailings and slimes behaves. Guimarães (2010) evaluated some mixtures of tailings and slimes and concluded that for mixtures with a high composition of tailings, an increase in the sedimentation velocity was observed.

Cylinder settling tests are widely used in the estimation of thickener sizes with the results from the tests being used to interpolate expected underflow densities as well as optimal feed conditions in full scale thickeners. The settling tests do however have a drawback of not being able to fully account for effects present in full scale thickening (Mclntosh, 2009).

\section{MATERIALS AND METHODS}

\subsection{Materials}

\subsubsection{Equipment:}

- 1000 mL graduated cylinder, pH meter, Marcy scale, cyclosizer, screens, stopwatch

\subsubsection{Samples:}

- Samples of slimes and flotation tailings collected from the Minas Rio processing plant.

\subsubsection{Reagents}

- Floerger SNF934 flocculant (anionic polymer).

- Floerger SNF920 flocculant (non-ionic).

- Lime for slurry pH control.

\subsubsection{Trials and conditions:}

\section{- Sample characterization}


Sample $\mathrm{pH}$ was determined with the $\mathrm{pH}$ meter and lime used to adjust the $\mathrm{pH}$ accordingly.

Sample solids percentage was determined with a Marcy Scale.

The granulometric distribution of the samples was determined using screens and the cyclosizer for the flotation tailings. The distribution of the slimes was determined using the cyclosizer.

\section{- Sedimentation tests}

The tests were classified in to batteries; Batteries 1, 2 and 3. Battery 1 and 2 were exploratory tests conducted using different proportions of slimes to tailings in order to assess the effect various proportions of the tailings and slimes would have on the settling process.

Battery 3 focused on sedimentation of a $100 \%$ slimes sample in order to assess how changing the sample $\mathrm{pH}$, flocculant type and flocculant dosage would affect the settling process.

Prior to the three batteries mentioned above, various sedimentation tests using various proportions of tailing to slimes, as well as flocculants from the supplier SNF Floerger were conducted. These tests showed that SNF934 performed better than other flocculants in most situations, hence it was used for the three batteries.

The exploratory sedimentation tests were realized according to Table 1 below. The volume/volume proportions were converted to determine the percentage tailings sent to the thickener in relation to the Minas Rio Project design:

Table 1. Sedimentation tests protocol for the exploratory tests (Battery $1 \& 2$ )

\begin{tabular}{|c|c|c|c|c|c|}
\hline Battery & $\begin{array}{c}\text { Proportion } \\
\text { Tailings /Slimes } \\
\text { (v/v) }\end{array}$ & $\begin{array}{l}\text { Tailings to } \\
\text { thickener in } \\
\text { relation to project } \\
\text { (\%) }\end{array}$ & Sample pH & Flocculant & $\begin{array}{c}\text { Flocculant } \\
\text { dosage } \\
(\mathrm{g} / \mathrm{t})\end{array}$ \\
\hline \multirow{4}{*}{1} & $2,3 / 1$ & 100 & \multirow{4}{*}{11,5} & \multirow{4}{*}{ SNF934 } & \multirow{4}{*}{$12 \& 24$} \\
\hline & $4 / 1$ & 59 & & & \\
\hline & $19 / 1$ & 12 & & & \\
\hline & $100 \%$ slimes & 0 & & & \\
\hline \multirow{4}{*}{2} & $2,3 / 1$ & 100 & \multirow{4}{*}{11,5} & \multirow{4}{*}{ SNF934 } & \multirow{4}{*}{$6,12 \& 24$} \\
\hline & $9 / 1$ & 26 & & & \\
\hline & $19 / 1$ & 12 & & & \\
\hline & $100 \%$ slimes & 0 & & & \\
\hline
\end{tabular}

Battery 3 which was conducted at $100 \%$ slimes was considered as a multi-level factorial design as it involved testing of three factors; sample $\mathrm{pH}$, flocculant type and flocculant dosage to evaluate their effect on the sedimentation process and water recovery. Table 2 shows the factors and levels tested in the multi-level factorial design for the $100 \%$ slimes sample. 
Table 2. Sedimentation tests protocol for Battery 3; factors and levels.

\begin{tabular}{|c|c|c|c|}
\hline Test & Flocculant type & $\begin{array}{c}\text { Flocculant } \\
\text { dosage }(\mathbf{g} / \mathbf{t})\end{array}$ & Sample $\mathbf{p H}$ \\
\hline 1 & SNF920 & 5 & 11,5 \\
\hline 2 & SNF920 & 5 & 12,0 \\
\hline 3 & SNF920 & 5 & 12,5 \\
\hline 4 & SNF920 & 15 & 11,5 \\
\hline 5 & SNF920 & 15 & 12,0 \\
\hline 6 & SNF920 & 15 & 12,5 \\
\hline 7 & SNF920 & 50 & 11,5 \\
\hline 8 & SNF920 & 50 & 12,0 \\
\hline 9 & SNF920 & 50 & 12,5 \\
\hline 10 & SNF934 & 5 & 11,5 \\
\hline 11 & SNF934 & 5 & 12,0 \\
\hline 12 & SNF934 & 5 & 12,5 \\
\hline 13 & SNF934 & 15 & 11,5 \\
\hline 14 & SNF934 & 15 & 12,0 \\
\hline 15 & SNF934 & 15 & 12,5 \\
\hline 16 & SNF934 & 50 & 11,5 \\
\hline 17 & SNF934 & 50 & 12,0 \\
\hline 18 & SNF934 & 50 & 12,5 \\
\hline
\end{tabular}

\section{RESULTS AND DISCUSSIONS}

The Minas Rio Project was designed for the volume/volume ratio of tailings to slimes sent to the thickener to be 2,3/1. Figure 2 below shows the settling velocity as a function of the tailings sent to the thickener in relation to the Minas Rio Project for the exploratory sedimentation tests conducted.

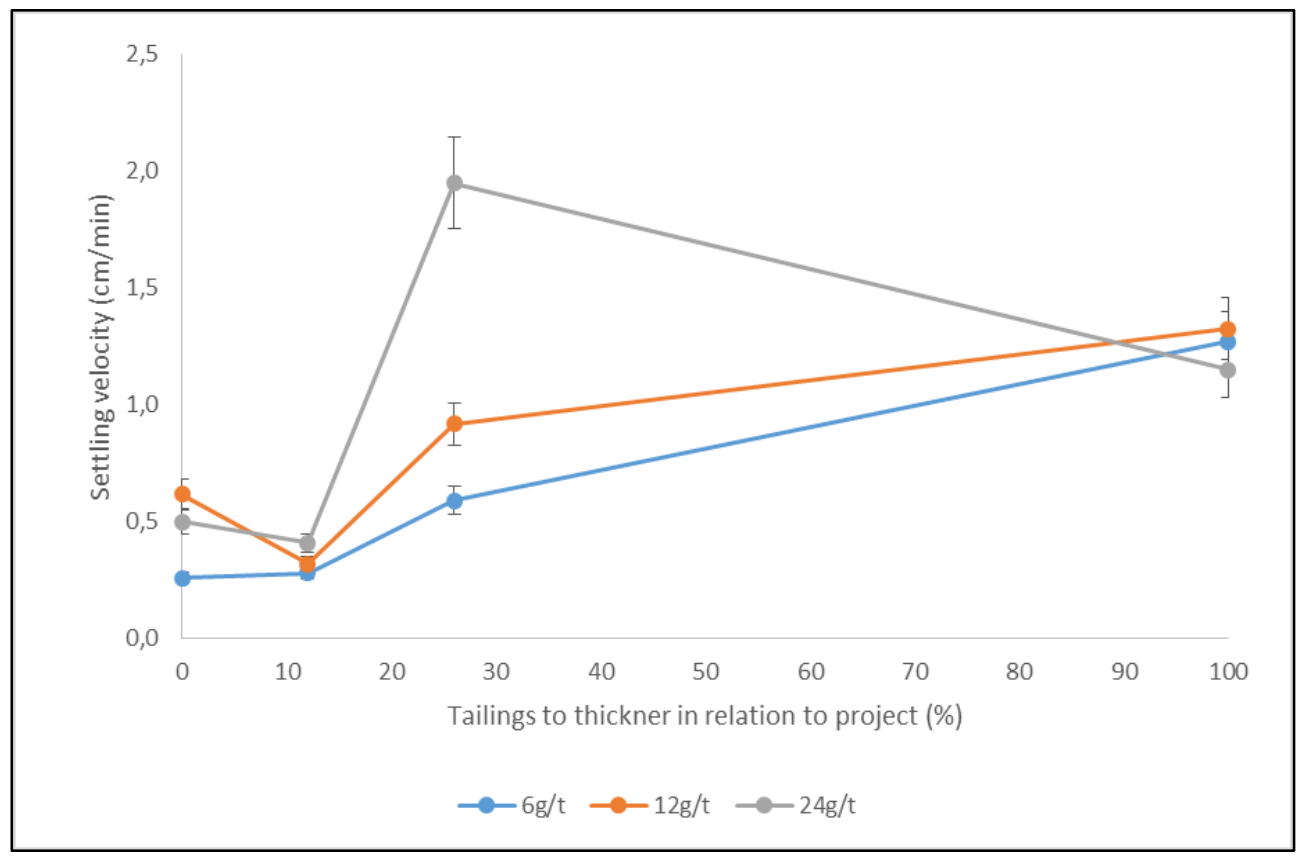

Figure 2. Thickener settling velocity vs \% tailings sent to thickener in relation to Project 
It was found that at the project ratio $2,3 / 1 \mathrm{v} / \mathrm{v}$ which represents $100 \%$ of the tailings sent the thickener in relation to the project, the settling velocity of the slurry at the three flocculant dosages tested $6 \mathrm{~g} / \mathrm{t}, 12 \mathrm{~g} / \mathrm{t}$ and $24 \mathrm{~g} / \mathrm{t}$ was $1,3 \mathrm{~cm} / \mathrm{min}, 1,3 \mathrm{~cm} / \mathrm{min}$ and $1,1 \mathrm{~cm} / \mathrm{min}$ respectively. Showing that the change in flocculant dosages did not have a significant effect on the settling velocity.

A significant increase in the settling velocity was observed at a flocculant dosage of $24 \mathrm{~g} / \mathrm{t}$ and with $26 \%$ of the tailings being sent to the thickener in relation to the Project. In the case where $100 \%$ slimes were sent to the thickener, representing $0 \%$ tailings to thickener in relation to project, the settling velocities observed for flocculant dosages of 6,12 and 24 were $0,3 \pm 0,02 \mathrm{~cm} / \mathrm{min}, 0,6 \pm 0,04 \mathrm{~cm} / \mathrm{min}$ and 0,5 $\pm 0,03$ $\mathrm{cm} / \mathrm{min}$ respectively.

Figure 3 shows the percentage solids in the underflow as a function of the percentage of tailings sent to the thickener in relation to the project.

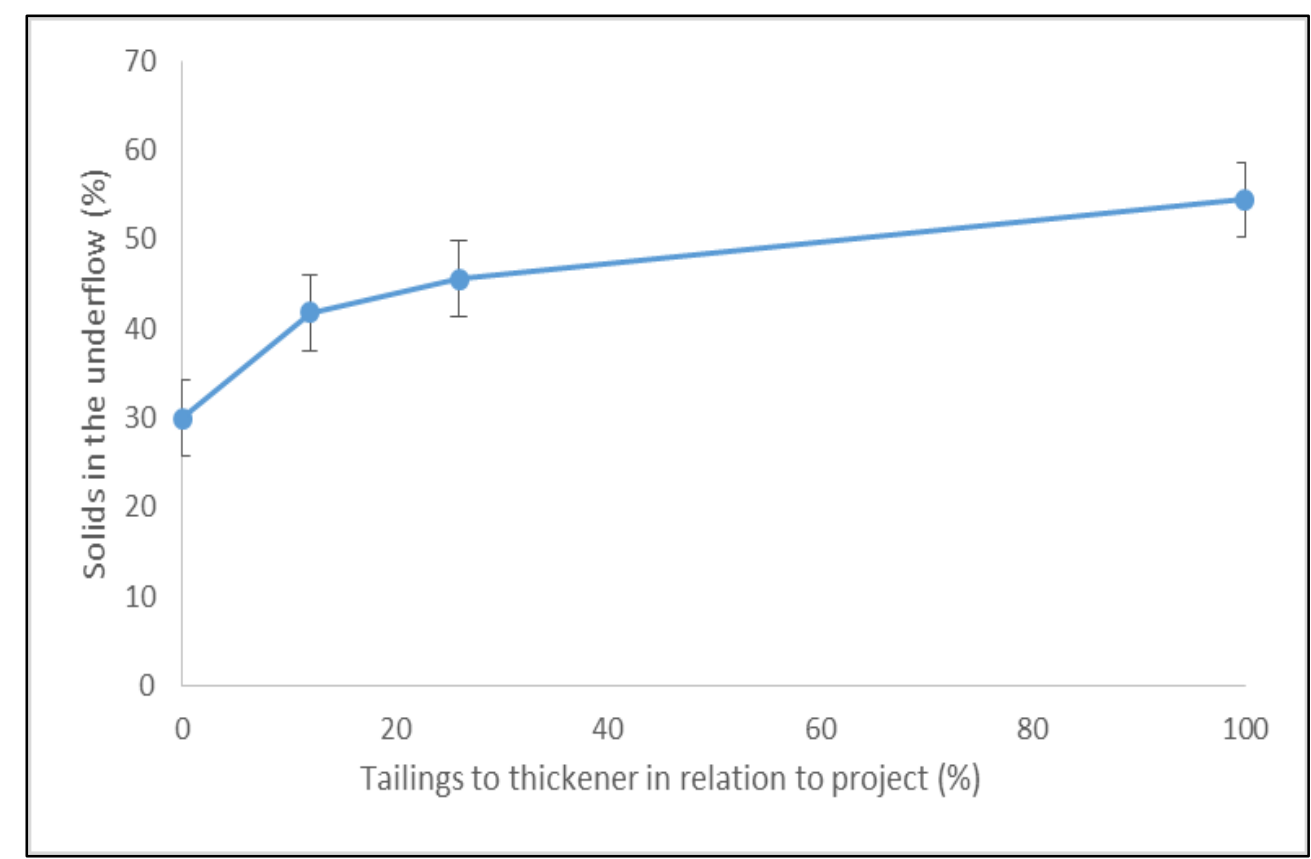

Figure 3. \% Solids in the underflow vs \% tailings sent to thickener in relation to Project

From the figure, at the ratio 2,3/1 tailings /slimes (v/v) which represents $100 \%$ of the tailings sent to thickener, the solids percentage is higher; $54,5 \pm 5,86 \%$. Whereas for a mixture of $100 \%$ slimes ( $0 \%$ tailings to thickener), the solids percentage is $30 \pm$ $2,30 \%$. The decrease in solids percentage implies a decreased water recovery in the thickener. 
Battery 3 of the tests was conducted with $100 \%$ slimes at three slurry pHs, two flocculant types and three flocculant dosages. Minitab ${ }^{\circledR}$ Statistical software was used to evaluate the effect of the three factors on the turbidity of the water, settling velocity and the percentage solids in the sediment (underflow). Figure 4 shows the interaction plot for the turbidity considering the three factors.

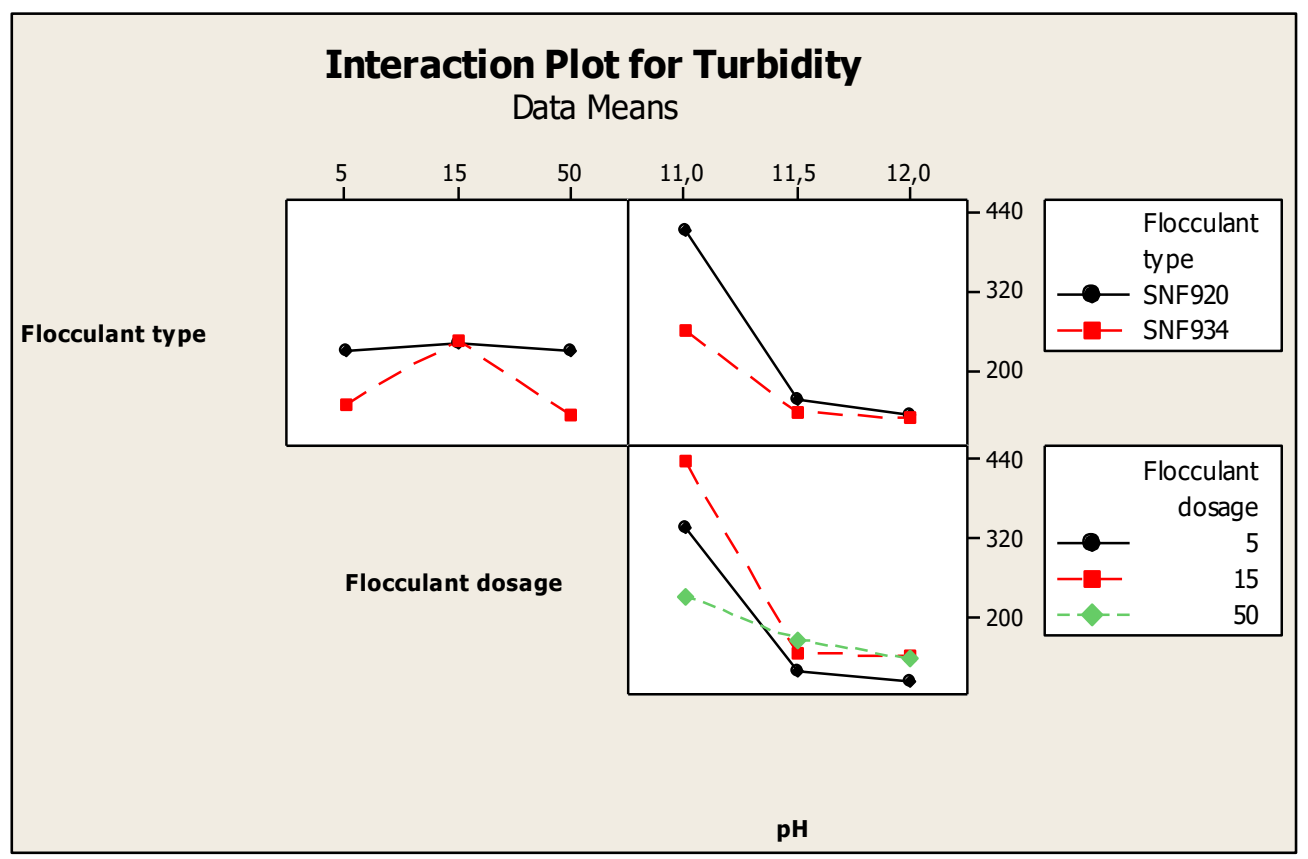

Figure 4. Interaction plot for turbidity (NTU)

Figure 4 shows that the lowest turbidity, 104 NTU, which translates to a better water clarity can be obtained with flocculant SNF920, at a dosage of $5 \mathrm{~g} / \mathrm{t}$ and a sample $\mathrm{pH}$ of 12,0 . This can be further shown with the contour plot in Figure 5.

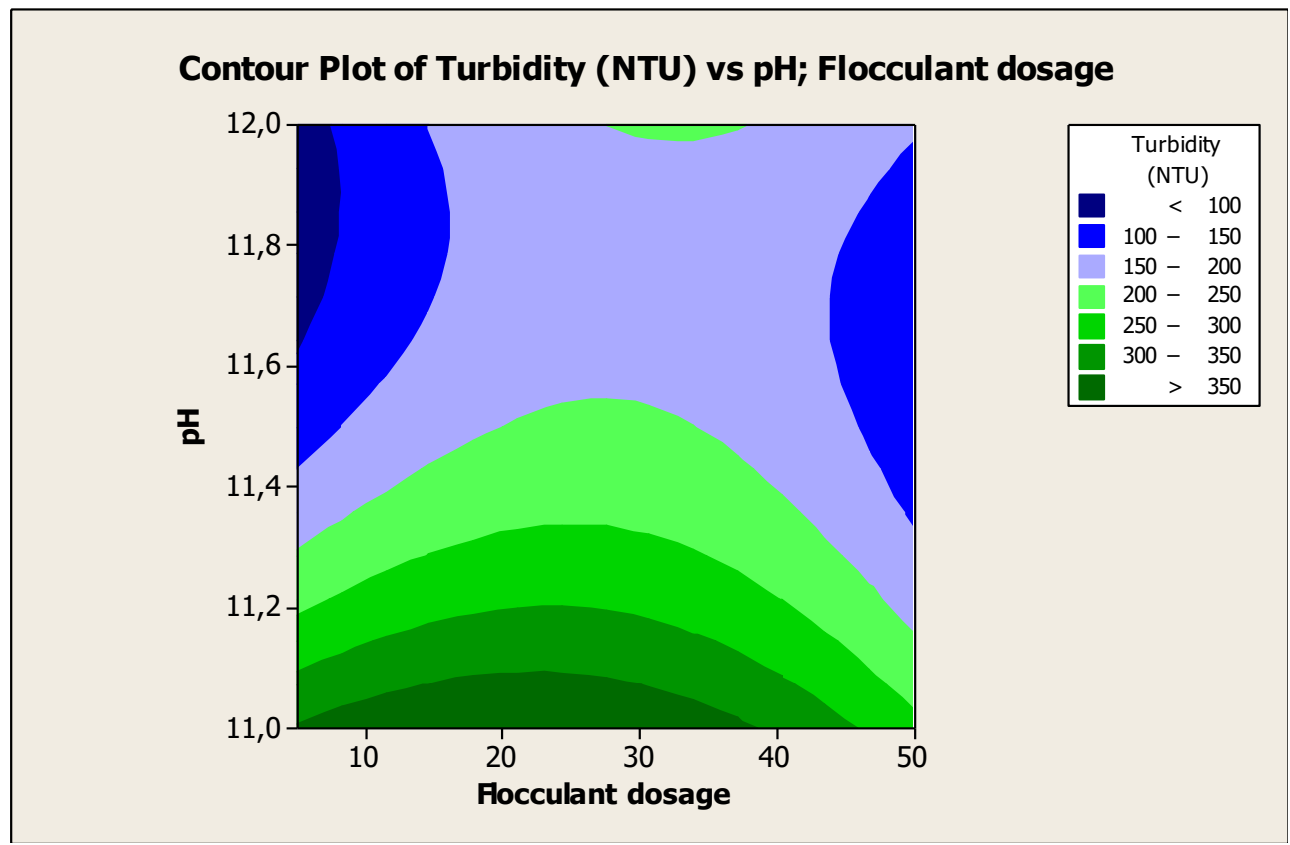

Figure 5. Contour plot for turbidity (NTU) 
Removal of flotation tailings from the feed to the thickener therefore affects water clarity, however there is an optimum operating point where water with a low turbidity can be obtained as demonstrated by Figures $4 \& 5$.

Figure 6 shows the interaction plot for the settling velocity considering the three factors.

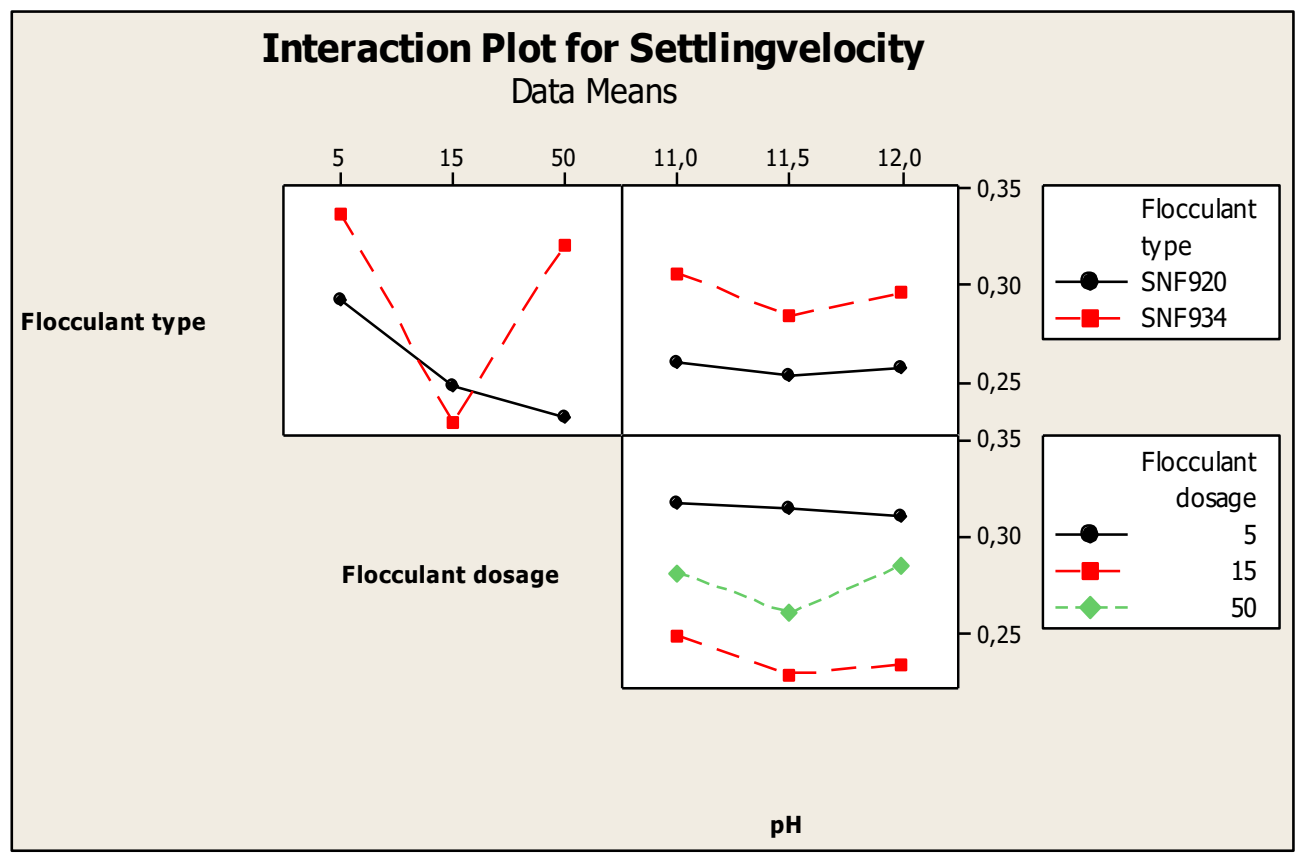

Figure 6. Interaction plot for settling velocity $(\mathrm{cm} / \mathrm{min})$

Figure 6 demonstrates that irrespective of the $\mathrm{pH}$ of the mixture, the settling velocities for SNF920 remained fairly in the same range. Furthermore, the highest settling velocity, $0,34 \mathrm{~cm} / \mathrm{min}$, can be achieved with SNF934, at a dosage of $5 \mathrm{~g} / \mathrm{t}$ and $\mathrm{a} \mathrm{pH}$ of 11 . This can be further shown with the contour plot in Figure 7 .

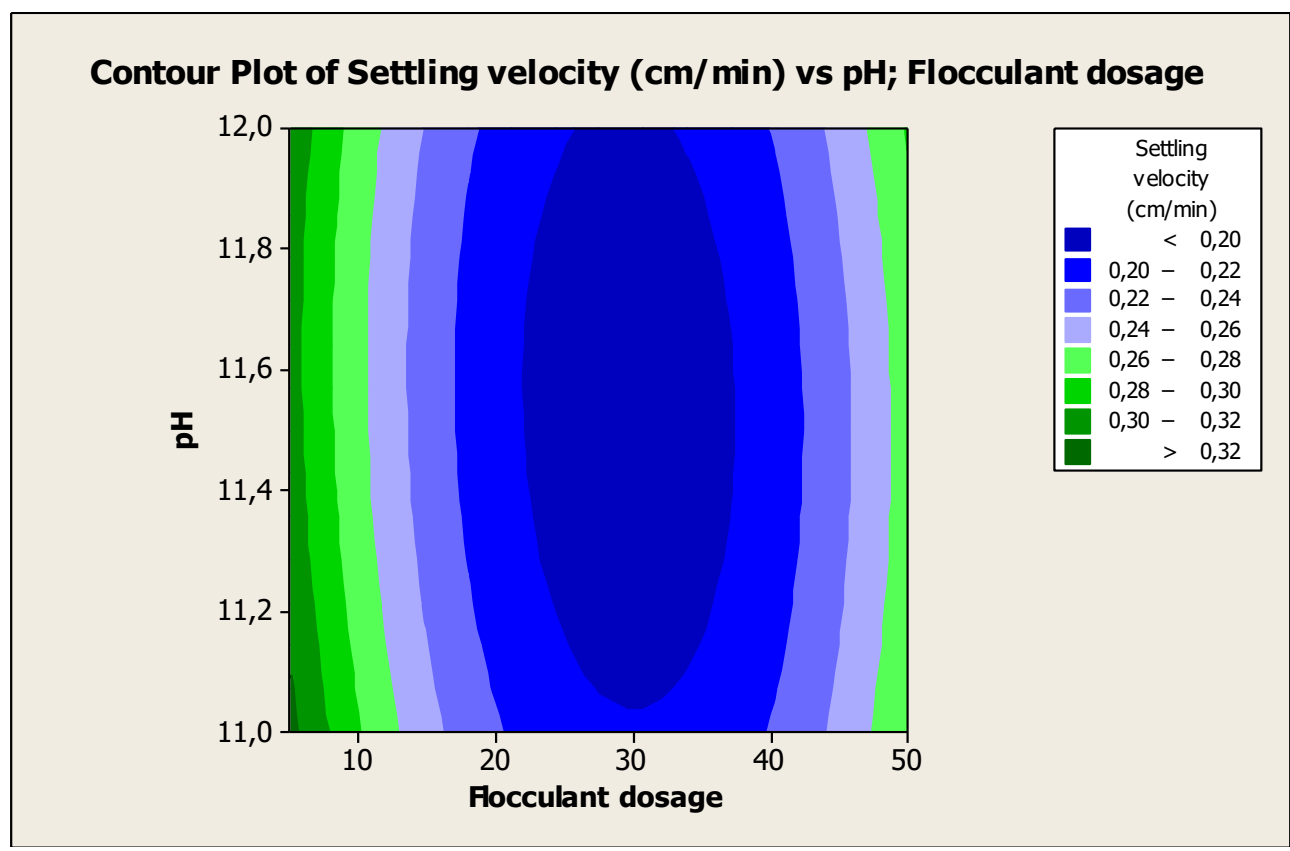

Figure 7. Contour plot for settling velocity $(\mathrm{cm} / \mathrm{min})$ 
Figure 8 shows the interaction plot for the percentage solids in the underflow (sediment) considering the three factors.

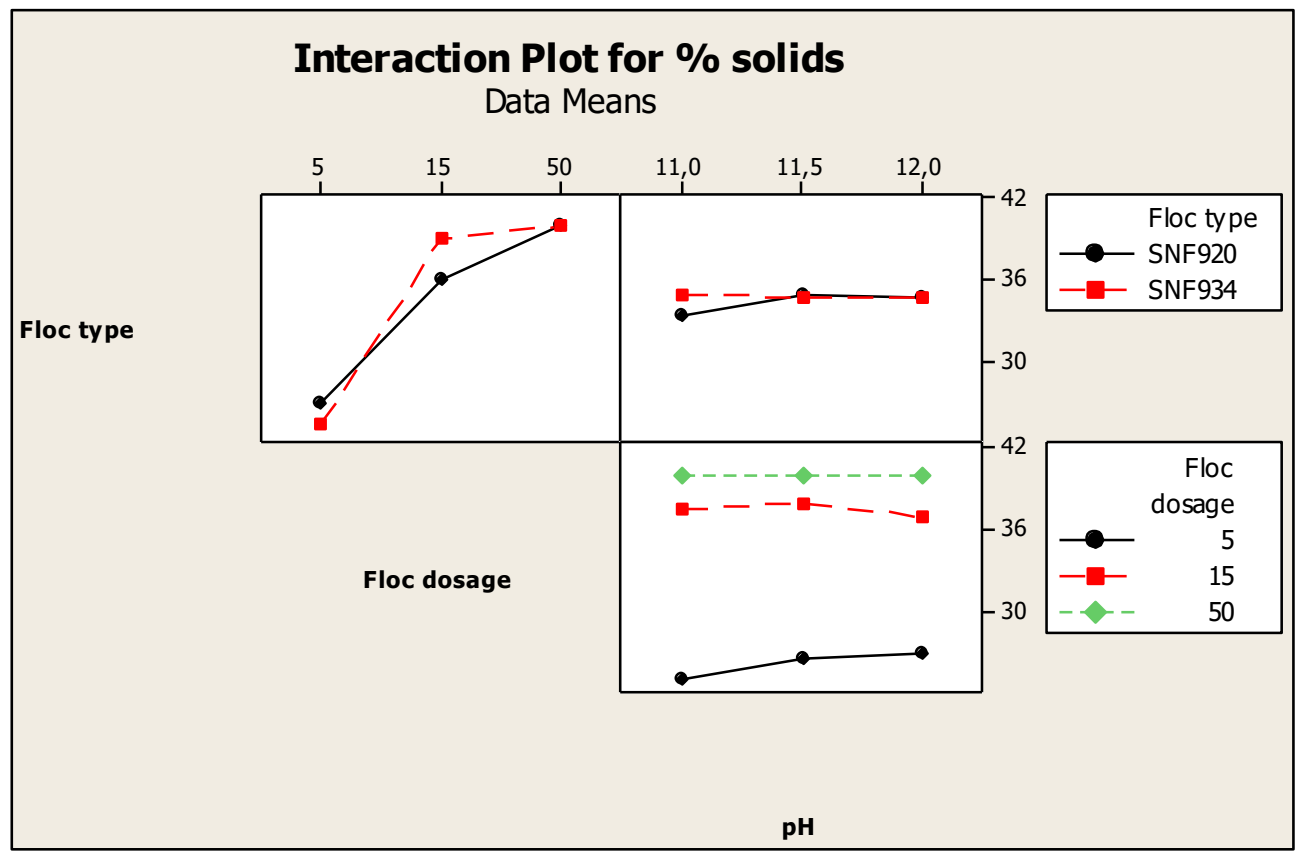

Figure 8. Interaction plot for \% solids in the underflow (sediment)

The largest percentage solids in the underflow, $40 \%$, in both cases of the SNF920 and SNF934 were observed at the highest flocculant dosage of $50 \mathrm{~g} / \mathrm{t}$. The $\mathrm{pH}$ change from 11 to 12 did not have a significant effect on the percentage solids in the underflow for each of the flocculant types. Figure 9 shows the contour plot for the percentage solids in the underflow (sediment).

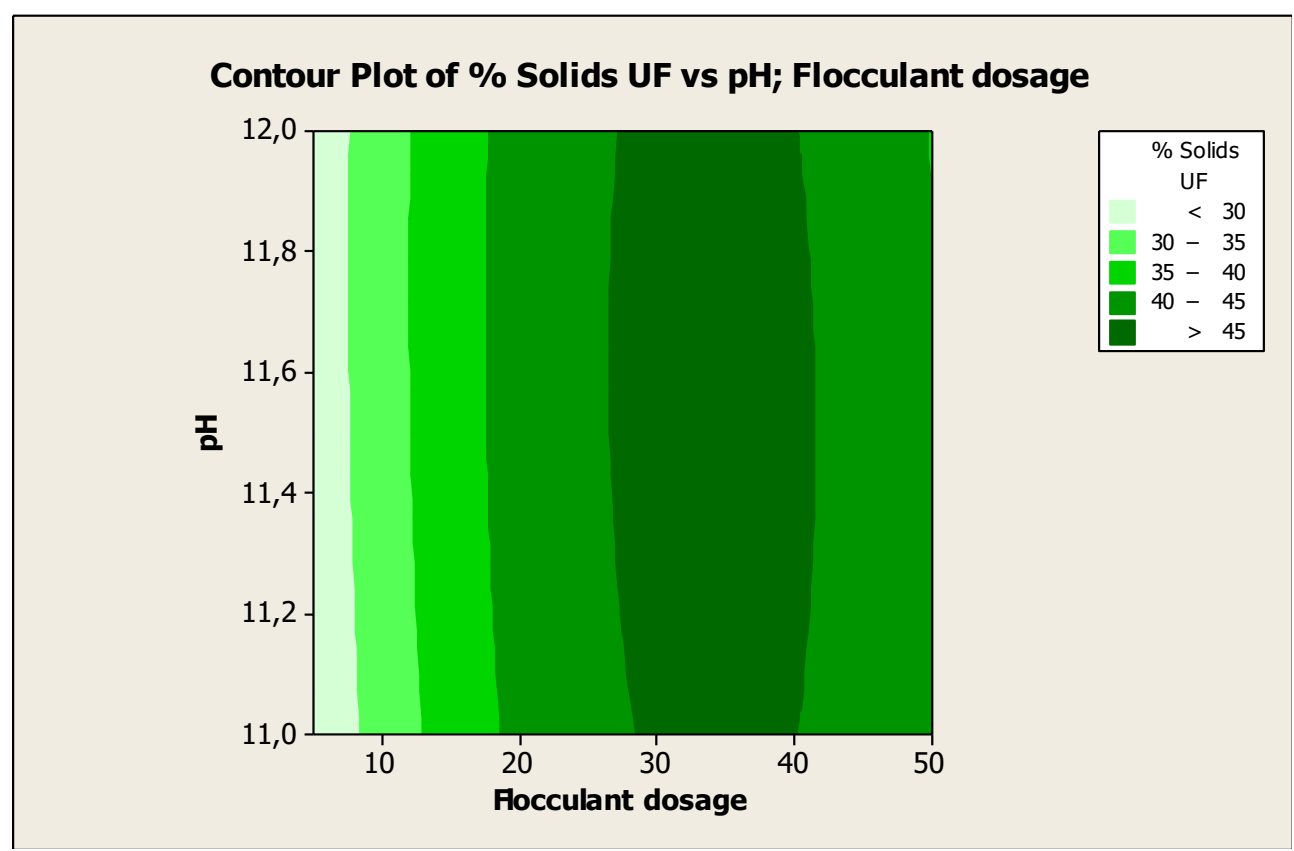

Figure 9.Contour plot for \% solids in the underflow 
The process to bypass the thickener and direct the flotation tailings to the tailings dam came into effect on 21 April 2017. Figures 10 \& 11 below show the evolution of the percentage solids in the underflow and the density of the underflow for the MinasRio thickener for a period 1 April to 30 April 2017.
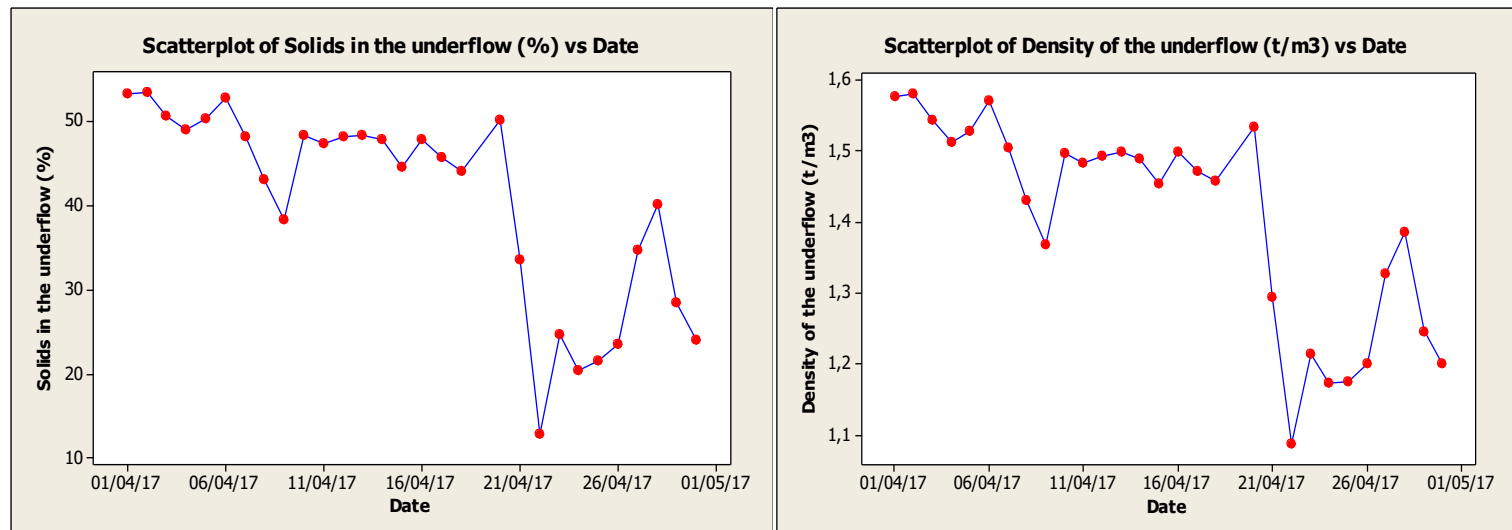

Figure 10. Solids in the underflow of the thickener. Figure 11. Density of the underflow of thickener.

The solids percentage in the underflow of the thickener can be seen decreasing from an average of $46,9 \pm 5,57 \%$ (1 April 2017 to 20 April 2017) to an average of 26,3 \pm $7,96 \%$ (21 April to 30 April). The underflow density can also be seen decreasing from an average of $1,49 \pm 0,073 \mathrm{t} / \mathrm{m}^{3}$ (1 April 2017 to 20 April 2017) to an average of $1,23 \pm 0,086 \mathrm{t} / \mathrm{m}^{3}$ (21 April to 30 April). With these changes in stream properties, the concern would be that the material arriving at the tailings dam could have a lower density and therefore affect dam life. However, since with the new configuration, the dam feed is the flotation tailings and the thickener underflow, there is a premise that the combined material density arriving at the dam remains the same.

Figure 12 shows the results of the calculated combined density for a period 15 May to 23 May.

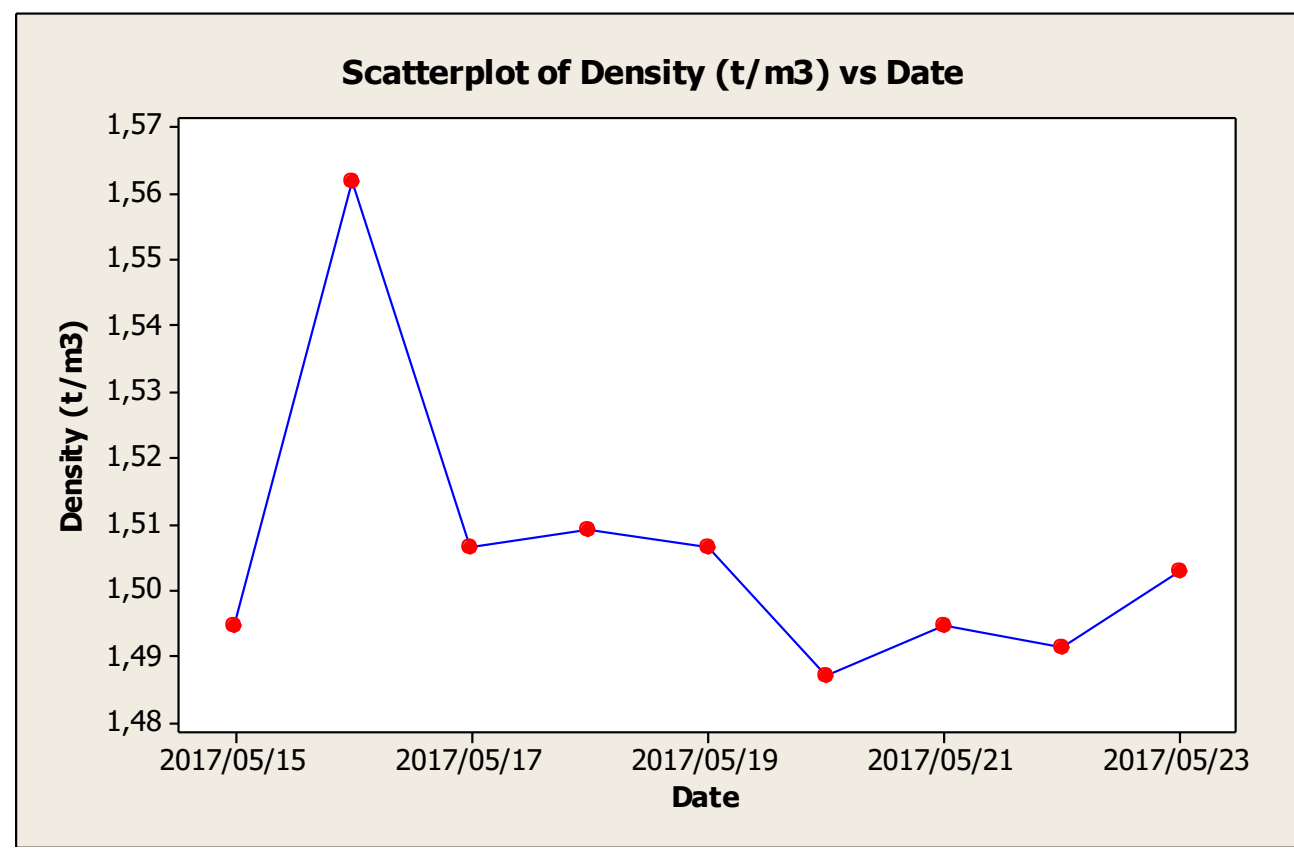

Figure 12. Overall density fed to the Minas Rio tailings 
From Figure 12 it can be seen that the overall density arriving at the dam has remained in the same range as the period 1 April to 20 April, with the average density being $1,51 \pm 0,0223 \mathrm{t} / \mathrm{m}^{3}$.

\section{CONCLUSIONS}

Based on the foregoing results and discussions, the following conclusions are made:

- Removal of the flotation tailings from the thickener feed mixture results in a reduced solids percentage for the underflow of the thickener as well as a reduced settling velocity of the material.

- The optimum conditions which obtain a low turbidity, good settling velocity and a high percentage of solids in the sediment for $100 \%$ slimes are; flocculant type SNF934, pH of 11,5 and high flocculant dosages.

- Whilst the removal of flotation tailings from the thickener feed is a viable option, downstream effects would have to be investigated. Furthermore, proportional diversion also remains a viable option, such that a certain portion, e.g 50\%, is sent to the thickener and another portion directly to the tailings dam.

\section{REFERENCES}

1. Parker B., Rivett T., Backeberg P., McIntosh A., El-Masry S., Heath A. White paper: Debottlenecking of Thickeners in a Changing Environment. 2016. Available in:

http://new.outotec.com/globalassets/services/documents/outotec_white_paper_de bottlenecking_of_thickeners_in_a_changing_environment.pdf

2. Mclntosh A. Thickener Sizing and Importance of Testwork. 2009. Available in: http://www.outotec.com/ImageVaultFiles/id_595/cf_2/Thickener_sizing_and_the_i mportance_of testwork.PDF

3. Guimarães FĀV. Revisão nos métodos de dimensionamento de espessadores e comparação dos modelos industriais. [mestrado]. Belo Horizonte:UFMG; 2010. 